\title{
MINI FICTIONS FOR WRITING EXPOSITORY ESSAYS
}

\author{
Lestari Setyowati and Sony Sukmawan \\ STKIP PGRI Pasuruan and University of Brawijaya \\ lestari.setyowati@yahoo.co.id sony_sukmawan@ub.ac.id
}

\begin{abstract}
Not many language teachers use literary works as teaching materials to teach language skills for their students. This is due to teachers' common perception that literature has a high degree of difficulty to understand. As a result, the use of literary works is often ignored to teach language skills, especially writing. Basically, if teachers are able to select literary works in accordance with the purpose of teaching and use it well, literature can be a bridge to improve language skills, especially the skills of writing an expository text. This article aims to describe the stages of teaching to teach writing skills through mini-fiction for expository essay, tips on choosing fictions that can be used in the classroom, and the problems that may arise from the use of these mini fictions. There are three stages of learning to be conducted when teaching writing skills by using mini fictions, namely the preparatory stage, pre-writing, and writing phases. Using literary works will be able to sharpen the students' language skills and their ability to think critically.
\end{abstract}

Keywords: Mini Fiction, Writing Skills, Expository Essay.

Having the ability to write is very important in this globalization era. Through writings, thoughts and ideas are obviously seen when stated on paper. Moreover, almost all jobs require good writing skills, such as secretaries, accountants, lawyers, doctors, police officers, public officials, administrators, journalists, teachers, professors, and many others. This writing skills needed to create memos, reports, letters, articles published electronically or in print media. Therefore, the inclusion of teaching writing skills is done early, from elementary school to college, although the teaching of this skill is integrated with other language skills.
However, writing is a skill that is a very difficult to master. It is not enough just to have an idea before writing. There are many other elements that must be mastered by the authors to be able to produce a piece of a good writing. Among the many elements of writing, organizing and developing ideas to form a united and coherent writing is very crucial since it will enable readers to understand the flow of ideas easily.

At the University level, having the ability to write is almost a must for every college students to have. This is reasonable since almost every task that is completed by the students requires written documents, such as papers, articles, reports assignments, 
thesis, and final projects. Therefore, it is important for students to improve the writing skills through continues practices. Moreover, it is also important for writing lecturers to constantly innovate strategies for teaching writing which are interesting for students so that they are always challenged to learn and produce a piece of writing.

Among the many genres of writing, expository type of essay is the most widely used in college. Expository text is a kind of writing that is used to explain, describe, and inform. This text is used to explain one topic and can be developed with various patterns or combinations of paragraph developments, for example based on time sequences, compare and contrast, causality (cause and effect relation), problem solving, and details Gordon, 1990).

Topics are usually given by writing teachers to teach the text expository are topics related to everyday life and has been widely known through the media, for example, about the dangers of smoking, the effects of drugs, the effects of the use of social media, natural disasters and global warming, online games, illegal logging, etc. However, teachers should be aware that with the advancement of technology today, these topics and sample essays can be found and read on the internet easily. They are even downloadable by smartphones and tablet usually brought by students to class.
To prevent and minimize plagiarism, there is a need to have new innovation of teaching materials that can be used for learning expository essay, one of them is with literary works. Not many teachers are interested to use the topics and materials derived from the literature because of the assumption that literature is difficult and complex so that it requires special skill to understand it. It is certainly not true. From the different kinds of literary genres, short story genre is one that can be used for learning to write expository essai.

Edgar Allan Poe, in his essay "The Philosophy of Composition," (Poe, in press) said that short story is a story which is readable in one sitting in which is the duration of time ranging from half an hour to two hours. In contemporary fiction, the number of words in a short story is in the range of 1,000 to 2,000 words. Therefore, in the short story usually there is only one main theme, one main character, and focusing on only at one plot (Notes, 2014). During its development, short stories have a new form of fiction, called mini fiction/flash fiction.

\section{MINI FICTION}

The term mini fiction or flash fiction emerged in the 1980s. At that time, there were two editors named Robert Shapard and James Thomas popularized and published a collection of flash fiction series or Sudden Fiction in which each story in the collection 
contains less than 2000 words (Sustana, 2015). Sustana also added that this type of flash fiction was growing in 1986 during World's Best Short Short Story Contest held by Jerome Stern, director of the creative writing from the University of Florida. At that time, Jerome Stern challenged the contestants to write an intact short story with no more than 250 words, though later he said the limit was raised to 500 words.

This type of short story is suitable to use in the essay writing class because it does not require a lot of time to read and understand the story. According to Emery (in press), flash fiction is a short story consisting of 300-1000 words. Some short stories that can be categorized as flash fiction are short stories written by Kate Chopin, such as The Blind Man and The Story of An Hour (Chopin, 2013).

\section{MINI FICTION WRITING EXPOSITORY ESSAY}

There are three stages of learning to be followed when teaching writing skills by using short stories, namely the preparatory stage, pre-writing, and writing phases.

\section{Preparation Phase}

The preparation phase aims to provide basic knowledge about the topic discussed. The basic knowledge is about the author of the fictions that will be read. There are several ways to prepare the background knowledge, for example by conducting a brief discussion in pairs, in groups, or in the form of a class discussion. Preparing the background knowledge can also be in the form of a guessing the vocabulary used in the story based on its title. Materials for discussion could revolve about the author and the characteristic of the works written, and whether they are familiar with it. If the students have never heard of these authors, a discussion could be about predicting what the fiction is about based on the short story title.

\section{Pre-Writing Stage}

At this stage, students are given exposure to the text to be read, either in writing or by using audio-visual media. It is important for teachers to allow students to read silently and enjoy the short stories for a couple of minutes without giving any tasks other than reading. After they read, discussions can be carried out either in small groups (2-3 people) or in the form of class discussions. This discussion aims to determine how far the students' understand the text they read. Materials for discussion are about the main idea, characters, setting, chronology of events, climax, anti-climax (if any), and messages that can be taken from the story. To make the discussion does not run long and boring, all should be prepared well in advance. When the students have shown adequate understanding of the text, then the teacher can move on to the next stage. 


\section{Writing Stage}

At the stage of writing, the students are asked to write his ideas about the story in the form of expository essay. To enable the students write his ideas in the form of an expository essay, the writing prompt should clearly ask them write an essay at this type. Examples of the writing prompt may be asking the students to compare the written version and the film version (compare and contrast essay), what to do when they are confronted with the type of literary texts that are difficult to understand (problem solution essay), or any moral message that can be drawn from the story that has been read (examples and details essay).

\section{THE STUDENTS' WORK}

The use of mini fiction has been practiced in essay writing class in April 2015 in STKIP PGRI Pasuruan At that time, students were asked to read short fiction written by Hans Christian Anderson's The Little Match Girl ( $\pm 1,021$ words). After reading the story about 10 minutes, the students were then asked to see the film version download from You Tube, lasted about 7 minutes. After a discussion about the similarities between the written version and the film version in terms of its intrinsic elements, students were then asked to write a rough draft of the differences and similarities between them for 15 minutes. The next learning activity was to write an essay of at least 250 words for 30 minutes based on the preliminary draft has been made. The result of the students' work is presented below.

In writing class, my teacher taught me about expository text. She tried to discuss about comparison essay in expository text and gave me two kinds of version of the story, the movie version and the original version. The story entitled "The Little Match Girl", which is written by Hans Christian Andersen in the original version and audio version have a difference and a similarity. The difference is in terms of characters and the similarity is in terms of setting.

The written version told me that the only character, the little match girl, is alone in the winter night. There is no other companion except a bunch of matches she holds to sell to the passerbys. But, in the movie version, I could see that there is another character that accompanies her in such a terrible weather. The other character is a little dog, a cute little puppy that could, at least, entertain her in her loneliness.

A similarity that I found between those versions of the story is a similarity in terms of setting. Exactly, the setting about circumstance from the both versions are completely similar. The maiden in the story seemed so sad in New Year's Eve, and it looked like it was so hard to find a person who interests in buying her matches. There was barely someone who cared about her alone in the cold temperature night. And still with the feeling of loneliness, she tried to enjoy herself to the cold because if she comes home without money in hand, she'll be scolded.

In conclusion, the similarity and the difference of the story don't change the exact message the writer wants to tell. Because the right message has been told in both versions without missing a piece. (Nora Syafiral Essay Writing/2013 C/292 words). 
From the example above, it can be seen that the student is able to elaborate the similarities and differences between the original version of a short story written by HC Andersen and the film version. Nora is able to compare two versions of the story from the point of view of setting and characters. She was also able to show similarities of both versions of the story in terms of the message given by the author. But it is so unfortunate that Nora does not elaborate further the moral value found in the short story The Little Match Girl.

\section{CHOOSING MINI FICTIONS}

There are several things to consider if literary works should be used for writing class. Teachers need to consider the length of the short story, the difficulty level of vocabulary and grammar, and the level of complexity of the storyline. Each will be discussed in the following section.

\section{The Fiction chosen should not be too long}

There is no standard amount of the number of words in a short story. A short story that is too long will make the students quickly lose their sense of his interest to keep on reading. In addition, teachers will also be difficult to arrange the learning phases for writing time. Too long short story will consume write time, since most time will be devoted to reading activities. Among the many examples of long short stories, some of them are shown here, such as The Most Dangerous Game by Richard Connell, The Gift of the Magi by O. Henry, or a series of short stories written by Sir Arthur Conan Doyle's famous characters, namely Sherlock Holmes. Short stories that can be used for writing class with limited hours is a kind of short stories that are not too long, with an estimated word count under 1,000 words. The appropriate type of short story is flash fiction (Emery, in press).

\section{The difficulty level of grammar and vocabulary.}

There are many short stories that have high level of difficulty in terms of language, such as The Lady or the Tiger by Frank Stockton and short stories written by Edgar Allan Poe. High degree of difficulty in terms of grammar and vocabulary will make the students quickly bored and not motivated to enjoy reading because they will more often see the dictionary to find the meaning of difficult words than interpret the short story itself. Therefore, teachers should select the type of short stories with a moderate difficulty level of grammar and vocabulary.

\section{The level of complexity of the storyline}

Short stories written by Edgar Allan Poe is known for the level of complexity in its plot. Short stories with a high level of complexity would require a long time to understand the plot. As a consequence, much time will be spent for solving this problems. 
If this is the case, the time which should be used for students to write, will be much taken for activities other than writing. Therefore, the appropriate type of short stories are those that have a moderate level of complexity.

\section{PROBLEMS THAT MAY ARISE}

Using literary works for writing skills will provide a challenge for teachers who use it. Some problems that may arise is about where to find, how to choose a suitable material, and whether the material is not too difficult for the students.

\section{Problem 1: Where can I find the material?}

Most teachers will be tempted to use the material they already know, for example the short stories they have learned during their study. But keep in mind that when they become teachers, the students they face are those who come from different generation. So, what they find interesting and up to date at that time, may not certainly interesting for students at this time. Therefore, teachers should always update their knowledge by reading. One of the easiest way to update the information of contemporer short stories is by using a search engine on the internet. There are many websites on the internet that offers a wide variety of flash fiction genres. Some of them are:

1. http://www.shortbreadstories.co.uk/story/ browse/text/genre/flash_fiction/. On this site, teachers can find a lot of flash fiction category. The writers write the stories with the word boundaries of 300-1000 words.

2. http://www.creative-writingnow.com/short-short-stories.html. On the web, there are also a lot of collection of flash fiction written by many young authors. The range of the number of words used are also still around 300-1000 words.

Teachers can also find a short stories in the form of audio-visual mode that is widely available on You Tube. To search on You Tube, the teacher can determine the theme before she starts looking for it on the internet by defining the themes such as friendship, mother, nature, children, animals, compassion, etc. Type in one of these themes in a search engine on You Tube, there will be a lot to choose from.

Problem 2: How to choose a suitable material?

To select suitable materials, teachers must understand the characteristics and abilities of their students, as well as the basic competence to be achieved based on the syllabus. When the student's ability is homogeneous and fall into the category of above average, then the short stories chosen can be much longer than the existing flash fiction category, eg short stories with a range of 1000-2000 words with moderate level of complexity of grammar and vocabulary. When the basic competence to be achieved is 
to write a text argument, then the short stories chosen should be a story that is able to give a lot of options on the readers so that they can take a stand, whether they should agree / disagree.

\section{CONCLUSION}

The term mini fiction may be something new to hear. But its existence in the literary genre is long enough that needs exploration to be used for teaching materials. When it is used appropriately and planned carefully, it offers an interesting challenge for both the teacher and the students. Surely, there will be problems that may arise in the use of literary works for teaching writing. But problems should not stop teachers to be innovative. With a spirit to help learners to learn to write better, using mini fictions for teaching writing can be an option to be used in EFL writing class. In sum, the use of literary works to train students to write an expository text can not only sharpen their skills to write, but also able to improve the students' analytical skills and critical thinking skills.

\section{REFERENCES}

Aalkadri. 2014. Flash Fiction collection. (Online) (http://www.wattpad.com/story/214915 25-flash-fiction-collection-by-ahmadalkadri), accessed 20 March 2015.
Chopin. Kate. 2013. Delphi Complete Works of Kate Chopin (Illustrated). Ebook of Delphi Classics. (Online) (https://books.google.co.id/books?20\% 20Chopin\&f), accessed $20 \mathrm{March}$ 2015.

Emery, Ian. In Press. A Crash Course in Flash Fiction. (Online) (http://uca.edu/writingcenter/files/2012 /06/Flash-Fiction.pdf), accessed 25 March 2015.

Gordon, Christine J. 1990. Modeling an Expository Text Structure Strategy in Think Alouds. Reading Horizon. Vol 31 (2). (Online) (http://scholarworks.wmich. edu/cgi/viewcontent.cgi? article $=1608 \&$ contex $\mathrm{t}=$ reading horizon s), accessed 6 June 2015.

Notes, Cliffs. 2014. What is a definition of short story? (online) (http://www.cliffsnotes. com/cliffsnotes/literature/what-is-adefinition-of-short-story), accessed 21 March 2015.

Poe, Edgar Allan. In Press. The Philosophy of Composition. (Online) (http://shortstoryamerica.com/pdf_class ics/poe_philosophy_of_composition.pd f), accessed 21 March 2015.

ShortBreadStories. 2015. Read Flash Fiction. (Online) (www.shortbreadstories.co.uk/story/ browse/text/genre/flash_fiction/), accessed 20 March 2015. Sustana, Chaterine. 2015. What Is Flash Fiction? (online) (http://shortstories.about.com/ od/Flash/a/What-Is-Flash-Fiction.htm), accessed 21 March 2015. 